\title{
IDŐBEN VÁLTOZÓ HŐÁTADÁS MATEMATIKAI MODELLJE ÉS CFD SZIMULÁCIÓJA
}

\author{
Takács Dávid \\ MSc hallgató, Energetikai és Vegyipari Gépészeti Intézet \\ 3515 Miskolc, Miskolc-Egyetemváros, e-mail: takdavid97@gmail.com \\ Erdős Antal \\ PhD hallgató, Energetikai és Vegyipari Gépészeti Intézet \\ 3515 Miskolc, Miskolc-Egyetemváros, e-mail: erdos@uni-miskolc.hu \\ Petrik Máté \\ tanársegéd, Energetikai és Vegyipari Gépészeti Intézet \\ 3515 Miskolc, Miskolc-Egyetemváros, e-mail: petrik@uni-miskolc.hu
}

\begin{abstract}
Absztrakt
Jelen tanulmányban a tranziens höátadás jelensége kerül tárgyalásra, konkrétan gördülöcsapágyak gördülö elemének vizsgálata a hökezelést követö lehülés során, golyó és henger esetén. Bemutatásra kerül a hővezetés elméleti és matematikai háttere és az alkalmazhatóságának határa, valamint a számítástechnikai háttérnek köszönhetöen ugyanezen probléma számitógépes (CFD) analízise.
\end{abstract}

Kulcsszavak: höátadás, gördülö csapágyak, CFD szimuláció

\begin{abstract}
In this present study the phenomenom of transient heat convection is discussed, specifically the examination of the rolling elements of the rolling bearings during cooling after the heat treatment. The theoretical and mathematical background of heat cunduction and convection and the limits of applicability, as well as the computational fluid dynamics (CFD) analysis of the same case are presented.
\end{abstract}

Keywords: heat convection, roller bearings, CFD analysis

\section{Bevezetés}

A természetben előforduló folyamatok többsége időben változik, emiatt leírásukhoz differenciálegyenletek alkalmazására van szükség. Ilyen jelenség a hővezetés is, amelyet a hővezetés általános differenciálegyenlete ír le. Ennek a felírásához a következő kiindulási feltételezésekkel kell élni: a tartomány, amelyre a vizsgálataink irányulnak legyen differenciálisan kicsiny $(\mathrm{d} V)$, és ebben a térfogatelemben termodinamikai egyensúly uralkodjon; a képzeletbeli cella válaszfalai a termikus kölcsönhatás számára átjárhatók legyenek. Ezek alapján az entalpia értéke:

$$
\mathrm{d} H=\rho \cdot c_{p} \cdot \mathrm{d} T \cdot \mathrm{d} V
$$


ahol $H$ az entalpia $[\mathrm{J} / \mathrm{kg}], \rho$ a közeg sürüsége $\left[\mathrm{kg} / \mathrm{m}^{3}\right], T$ a hömérséklet $[\mathrm{K}]$ és a $c_{p}$ az állandó nyomásra érvényes fajhő $[\mathrm{J} /(\mathrm{kgK})]$.

$\mathrm{Az}$ energiamegmaradás tétele érvényes, azaz a cellába be- és kilépő energia különbsége és a felhalmozódó energia teljesen az entalpia megváltozására fordítódik. A tartományban az intenzív állapotjelző (hőmérséklet) térbeli inhomogenitása az oka az extenzív állapotjelző (energia) térbeli transzportjának, amit mennyiségileg a vezetési egyenlet - Fourier-törvény - ír le. Ezt szemlélteti egy tökéletesen merev, nyugvó szilárd test $\mathrm{d} V$ egységnyi térfogateleme, a ki- és belépö energiát derékszögü koordináta rendszerben ábrázolva az 1. ábrán.

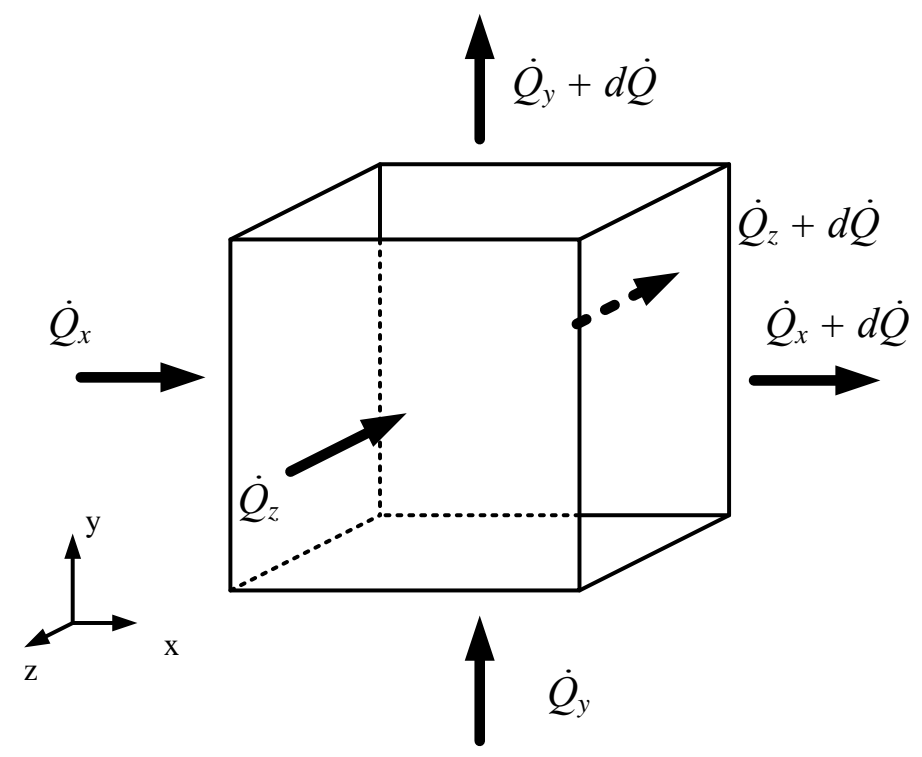

1. ábra: Egységnyi térfogatba be- és kilépö energia

Felírva az energiamérleget a rendszerre, az alábbi összefüggés adódik:

$$
\dot{q}_{V} \cdot \mathrm{d} x \mathrm{~d} y \mathrm{~d} z-\left[\frac{\partial}{\partial x} \cdot\left(-\lambda \cdot \frac{\partial T}{\partial x}\right)+\frac{\partial}{\partial y} \cdot\left(-\lambda \cdot \frac{\partial T}{\partial y}\right)+\frac{\partial}{\partial z} \cdot\left(-\lambda \cdot \frac{\partial T}{\partial z}\right)\right] \cdot \mathrm{d} x \mathrm{~d} y \mathrm{~d} z=\rho \cdot c_{p} \cdot(\mathrm{d} x \mathrm{~d} y \mathrm{~d} z) \cdot \frac{\partial T}{\partial t}
$$

melyből levezethető a hővezetés általános differenciálegyenletének koordináta rendszertől független, állandó együtthatójú alakja:

$$
\frac{\dot{q}_{V}}{\rho \cdot c_{p}}+a \cdot \nabla^{2} \cdot T(\underline{r}, r)=\frac{\partial T(\underline{r}, r)}{\partial t}
$$

ahol az $a$-val jelölt anyagjellemző a hőmérséklet-vezetési tényező $\left(a=\frac{\lambda}{\rho \cdot c_{p}}\right)$. Ez a differenciálegyenlet müködik időben állandó hővezetés esetében is, ilyenkor a jobb oldal zérus, így a fenti egyenlet közönséges differenciálegyenletté válik. Az időben változó hővezetési feladatok megoldása azt jelenti, hogy meghatározzuk azt a $T(\underline{r}, r)$ függvényt, amely megoldása a hővezetés differenciálegyenletének, továbbá kielégíti a peremfeltételeket. A $T(\underline{r}, r)$ függvény előállításához továbbá ismernünk kell a kezdeti időpillanatra érvényes hőmérséklet eloszlást, amit kezdeti feltételnek 
is neveznek. Hővezetés esetében alapvetően háromféle peremfeltétel különböztethető meg, melyek az első- másod- és harmadfajú peremfeltételek:

- elsőfajú a peremfeltétel: ha a tartomány adott határán a hőmérséklet értéke ismert,

- másodfajú a peremfeltétel: ha a tartomány adott határán ismert a $\dot{q}_{V}$ hőáramsűrüség,

- harmadfajú a peremfeltétel: ha a tartomány adott határán a hőáramsürüség arányos a test felszíni és a környezet hőmérsékletének a különbségével.

Két fizikai jelenség hasonló, ha az azokat leíró differenciálegyenletek értelmezési tartományban, értékkészletükben és peremfeltételeikben hasonlóak.

A differenciálegyenlet egyszerüsítésére alkalmazható a dimenziótlanítás, melynek több előnye is van. A két legfontosabb az, hogy csökkenti az ismeretlenek számát és más fizikai jelenségekre is alkalmazható a megoldás, amennyiben az kielégíti a hasonlósági feltételeket.

A $\theta$ (dimenziótlan hőmérséklet) és $X$ (dimenziótlan hossz) változók bevezetése után a hővezetés differenciálegyenlete:

$$
\frac{L^{2}}{a} \cdot\left(T_{0}-T_{\infty}\right) \cdot \frac{\partial \theta}{\partial t}=\left(T_{0}-T_{\infty}\right) \cdot\left(\frac{\partial^{2} \theta}{\partial X^{2}}+\frac{n}{X} \cdot \frac{\partial \theta}{\partial X}\right) .
$$

Bevezetve a Fourier-számot, amely a hőmérséklet-eloszlások időbeli hasonlósági kritériuma. A különböző anyagjellemzőkkel rendelkező testek és azonos hasonlósági kritérium esetén ugyanazt a megoldást kapjuk.

$$
F o=\frac{a \cdot t}{L^{2}}
$$

Így az előző differenciálegyenlet:

$$
\frac{\partial \theta}{\partial F o}=\frac{\partial^{2} \theta}{\partial X^{2}}+\frac{n}{X} \frac{\partial \theta}{\partial X}
$$

A peremfeltételek hasonlóságának kérdését a harmadfajú peremfeltételek esetére vizsgálva:

$$
\left.\frac{1}{\theta_{w}} \cdot \frac{\mathrm{d} \theta}{\mathrm{d} X}\right|_{w}=\frac{\alpha L}{\lambda}=B i .
$$

Az összefüggésben szereplö $w$ a falra utal, az $\alpha$ pedig a höátadási tényező. Ennek az egyenletnek a jobb oldalán álló dimenziótlan mennyiség a Biot-szám, jelölése Bi. Ez nem más, mint a harmadfajú peremfeltétel hasonlóságát biztosító feltétel.

\section{Koncentrált paraméterü modell}

Koncentrált paraméterü modellt alkalmazhatunk abban az esetben, amennyiben a vizsgált fizikai rendszert jellemzö összefüggések az adott térrészben kiátlagolhatók, és egyetlen összefüggéssel kiválthatók. Ennek a modellnek az alkalmazhatósága függ a test méretétől. A hővezetés során kialakuló hőmérséklet állandónak tekinthető a teljes térfogatban, emiatt a hőmérséklet csak az időtől függ. Ekkor a testtel közölt hő a test belső energiáját növeli. Jelen tanulmányban csak olyan esetek kerültek vizsgálva, melyekre érvényesek a modell korlátai [1], [2]. 
Felírva a Newton-féle hővezetési modellt:

$$
T(t)=\left(T_{i}-T_{\infty}\right) \cdot e^{-\frac{\alpha \cdot A_{s}}{\rho \cdot c_{p} \cdot V} \cdot t}+T_{\infty},
$$

ahol $T_{i}$ a test kezdeti hőmérséklete, $A_{s}$ a höátadó felület, $T_{\infty}$ pedig a végtelennek tekintett tér hőmérséklete. Ez a modell abban az esetben alkalmazható, ha a Biot-szám nagysága kisebb, mint 0,1. Ez a Biot-szám a testbe hőátadással érkező hő és a testen belüli hővezetés arányaként számítható [3].

Összefüggése:

$$
B i=\frac{\alpha \cdot L_{c}}{\lambda}
$$

A Bi-szám összefüggése a jellemzőket figyelembe véve megegyezik a Nu-szám kiszámítási módjával, itt azonban a $\lambda$ hővezetési tényező a szilárd testre vonatkozik, nem pedig az áramló fluidumra. Az $L_{c}$ jellemző geometria a hőátadó felület és a térfogat hányadosaként értelmezendő [4].

$$
L_{c}=\frac{V}{A_{s}}
$$

A természetes és szabad konvekció esetén is hasonlósági számokat lehet alkalmazni. Ezek a számok megkönnyítik a hővezetéssel kapcsolatos számításokat [5]. A szükséges hasonlósági számok:

- Nusselt-szám: a tényleges hőáramsürüség és az $l$ vastagságú rétegen keresztüli tiszta hővezetés viszonyát fejezi ki:

$$
N u=\frac{\alpha \cdot l}{\lambda}
$$

- Prandtl-szám: az impulzustranszport és a vezetés útján történő transzport hányadosa (a kinematikai viszkozitás és a hőmérsékletvezetési tényező hányadosa):

$$
\operatorname{Pr}=\frac{c_{p} \cdot \eta}{\lambda}=\frac{v}{a}
$$

- Grashof-szám: a fluidumra ható felhajtóerő és a belső súrlódó erő hányadosát adja meg:

$$
G r=\frac{g \cdot \beta \cdot l^{3} \cdot \rho^{2} \cdot\left(T-T_{f a l}\right)}{\eta^{2}}
$$

ahol $g$ a gravitációs gyorsulás, a $\beta$ pedig a köbös hőtágulási együttható.

- Rayleigh-szám: a szabad konvekciós közegek diffúziós és konvekciós hőátadásának hányadosát fejezi ki:

$$
R a=\operatorname{Pr} \cdot G r=\frac{g \cdot \beta \cdot l^{3} \cdot \rho^{2} \cdot\left(T-T_{f a l}\right) \cdot c_{p}}{\eta \cdot \lambda},
$$

- Reynolds-szám: a folyadékra ható tehetetlenségi erők és a súrlódó erők viszonyát fejezi ki:

$$
R e=\frac{v \cdot l}{v}=\frac{v \cdot l \cdot \rho}{\eta} \text {. }
$$


Szabad konvekciónál henger esetén két további eset különböztethető meg:

- ha a henger hossztengelye függöleges,

- ha a henger hossztengelye vízszintes.

A hengergörgős csapágyak szempontjából az utóbbi eset a mérvadó, hiszen a gyártási folyamat során nem fordítanak figyelmet a hengerek álló helyzetbe hozására. Ebben az esetben a hossztengely vízszintes, alkalmazható, ha $\mathrm{Ra} \leq 10^{12}[6]$ :

$$
N u=\left\{0,6+\frac{0,387 \cdot R a^{1 / 6}}{\left[1+\left(\frac{0,559}{P r}\right)^{9 / 16}\right]^{8 / 27}}\right\}^{2} .
$$

Gömb és henger körüli áramlás esetén:

- gömb (ha $3,5 \leq \operatorname{Re} \leq 80000$ és $0,7 \leq \operatorname{Pr} \leq 380$ ) [7]

$$
N u=2+\left[0,4 \cdot R e^{1 / 2}+0,06 \cdot \operatorname{Re}^{2 / 3}\right] \cdot \operatorname{Pr}^{0,4} \cdot\left(\frac{\eta}{\eta_{f a l}}\right)^{0,14},
$$

- henger $(\operatorname{Re} \cdot \operatorname{Pr} \geq 0,2)$

$$
N u=0,3+\frac{0,62 \cdot \operatorname{Re}^{1 / 2} \cdot \operatorname{Pr}^{1 / 3}}{\left[1+\left(\frac{0,4}{P r}\right)^{2 / 3}\right]^{1 / 4}} \cdot\left[1+\left(\frac{R e}{282000}\right)^{5 / 8}\right]^{4 / 5}
$$

Természetesen ez a koncentrált paraméterü modell nem csak ilyen egyszerü geometriájú testek hőátadására alkalmazható, hanem bonyolult alkatrészek esetén is, mint például porózus térfogatú testek [8] vagy bordák [9] hőátadásának elemzésekor is.

\section{Koncentrált paraméterü modell alkalmazása}

Jelen tanulmányban 5 különböző méretü csapágygolyó és 2 eltérő méretü henger hülése lett vizsgálva szabad konvekciós és kényszer konvekciós állapotokban:

- gömb geometria, szabad konvekció $(v=0)$,

- gömb geometria, kényszer konvekció $(v \neq 0)$,

- henger geometria, szabad konvekció $(v=0)$,

- henger geometria, kényszer konvekció $(v \neq 0)$.

A számításokban acél alapanyag volt feltételezve, és a viszonylag kis mértékủ hőmérséklettartomány miatt az anyagjellemzők hőmérsékletfüggésétől eltekintettünk. A Bi-szám meghatározásához a következő jellemzőkre van szükség. 
1. táblázat. A gördülő elem anyagjellemzői

\begin{tabular}{|c|c|c|c|}
\hline & jele & értéke & dimenziója \\
\hline sürüség & $\rho_{c}$ & 7850 & $\mathrm{~kg} / \mathrm{m}^{3}$ \\
\hline hővezetési tényező & $\lambda_{c}$ & 43 & $\mathrm{~W} /(\mathrm{m} / \mathrm{K})$ \\
\hline fajhő & $c_{c}$ & 465 & $\mathrm{~J} /(\mathrm{kg} / \mathrm{K})$ \\
\hline
\end{tabular}

\section{1. $D=8 \mathrm{~mm}$ átmérőjü és $L=10 \mathrm{~mm}$ hosszúságú, $T_{T}=170^{\circ} \mathrm{C}-0 \mathrm{~s}$ csapágy görgő hülése szabad konvekcióval}

A közeg anyagjellemzőit tartalmazza a fenti táblázat $T_{k}=97,5^{\circ} \mathrm{C}$-on. A henger vízszintes helyzetü, aminek jellemző geometriai mérete a $D$ átmérô. Szabad konvekciónál a $\mathrm{Gr}$ és Pr szám függvényében határozhatjuk meg a Nu-szám értékét.

$$
G r=\frac{g \cdot \beta \cdot D^{3} \cdot \rho^{2} \cdot\left(T-T_{f a l}\right)}{\eta^{2}}=\frac{g \cdot 0,003411 \frac{1}{\mathrm{~K}} \cdot(0,008 \mathrm{~m})^{3} \cdot\left(0,953 \frac{\mathrm{kg}}{\mathrm{m}^{3}}\right)^{2} \cdot\left(170^{\circ} \mathrm{C}-25^{\circ} \mathrm{C}\right)}{\mathrm{Gr}=4791,318^{0,0000217 \mathrm{Pas}^{2}}}
$$

A Pr-szám csak a közeg anyagjellemzőitől függ:

Ezekböl a Ra-szám:

$$
\operatorname{Pr}=\frac{c_{p} \cdot \eta}{\lambda}=\frac{1011 \frac{\mathrm{J}}{\mathrm{kgK}} \cdot 0,0000217 \mathrm{Pas}}{0,0313 \frac{\mathrm{W}}{\mathrm{mK}}}=0,7009
$$

$$
R a=G r \cdot P r=4791,3183 \cdot 0,7009=3358,3161
$$

Henger esetén a tapasztalati Nusselt-szám összefüggésének alkalmazhatósági feltétele teljesül szabad konvekciónál, mivel: $\mathrm{Ra} \leq 10^{12}$, igy a Nu-szám értéke:

$$
N u=\left\{0,6+\frac{0,387 \cdot R a^{1 / 6}}{\left[1+\left(\frac{0,559}{P r}\right)^{9 / 16}\right]^{8 / 27}}\right\}^{2}=\left\{0,6+\frac{0,387 \cdot 3358,3161^{1 / 6}}{\left[1+\left(\frac{0,559}{0,7009}\right)^{9 / 16}\right]^{8 / 27}}\right\}^{2}=3,393,
$$

melyből a hőátadási tényező értéke:

$$
\alpha=\frac{N u \cdot \lambda}{D}=\frac{3,393 \cdot 0,0313 \frac{\mathrm{W}}{\mathrm{mK}}}{0,008 \mathrm{~m}}=13,275 \frac{\mathrm{W}}{\mathrm{m}^{2} \mathrm{~K}} .
$$

A koncentrált paraméterü modell alkalmazásához meg kell határozni a geometriai jellemzőket:

$$
\begin{gathered}
V=\frac{D^{2} \cdot \pi}{4} \cdot L=\frac{(0,008 \mathrm{~m})^{2} \cdot \pi}{4} \cdot 0,01 \mathrm{~m}=5,026 \cdot 10^{-7} \mathrm{~m}^{3}, \\
A=2 \cdot \frac{D^{2} \cdot \pi}{4}+D \cdot \pi \cdot L=2 \cdot \frac{(0,008 \mathrm{~m})^{2} \cdot \pi}{4}+0,008 \mathrm{~m} \cdot \pi \cdot 0,01 \mathrm{~m}=0,0003519 \mathrm{~m}^{2}, \\
L_{c}=\frac{V}{A}=\frac{5,02655 \cdot 10^{-7} \mathrm{~m}^{3}}{0,0003519 \mathrm{~m}^{2}}=0,001429 \mathrm{~m} . \\
104
\end{gathered}
$$


Ezekből a Bi-szám értéke:

$$
B i=\frac{\alpha \cdot L_{c}}{\lambda}=\frac{13,2754 \frac{\mathrm{W}}{\mathrm{m}^{2} \mathrm{~K}} \cdot 0,001429 \mathrm{~m}}{43 \frac{\mathrm{W}}{\mathrm{mK}}}=0,000441 .
$$

Mivel $B i \leq 0,1$, ezért a koncentrált paraméterü modell alkalmazható a vizsgált szabad konvekciós esetre. A Newton-féle összefüggésben szereplő időállandó értéke:

$$
b=\frac{\alpha \cdot A_{s}}{\rho \cdot c_{p} \cdot \mathrm{V}}=\frac{13,2754 \frac{\mathrm{W}}{\mathrm{m}^{2} \mathrm{~K}} \cdot 0,0003519 \mathrm{~m}^{2}}{7850 \frac{\mathrm{kg}}{\mathrm{m}^{3}} \cdot 465 \frac{\mathrm{J}}{\mathrm{kgK}} \cdot 5,02655 \cdot 10^{-7} \mathrm{~m}^{3}}=0,002546 \frac{1}{\mathrm{~s}}
$$

melyből meghatározva a görgő hőmérsékletét 30 s-mal később a következő értéket kapjuk:

$$
T(30)=\left(T_{i}-T_{\infty}\right) \cdot e^{-b \cdot t}+T_{\infty}=\left(170^{\circ} \mathrm{C}-25^{\circ} \mathrm{C}\right) \cdot \mathrm{e}^{-0,002546 \frac{1}{\mathrm{~s}} \cdot 30 \mathrm{~s}}+25^{\circ} \mathrm{C}=159,3^{\circ} \mathrm{C} .
$$

Annak érdekében, hogy a matematikai modell megfelelössége biztosításra kerüljön, a vizsgált hőátadási esetre CFD analízis készült. A vizsgálat az SC-Tetra kereskedelmi forgalomban kapható szoftverrel lett elvégezve, és a futtatás eredménye a 2. ábrán látható.

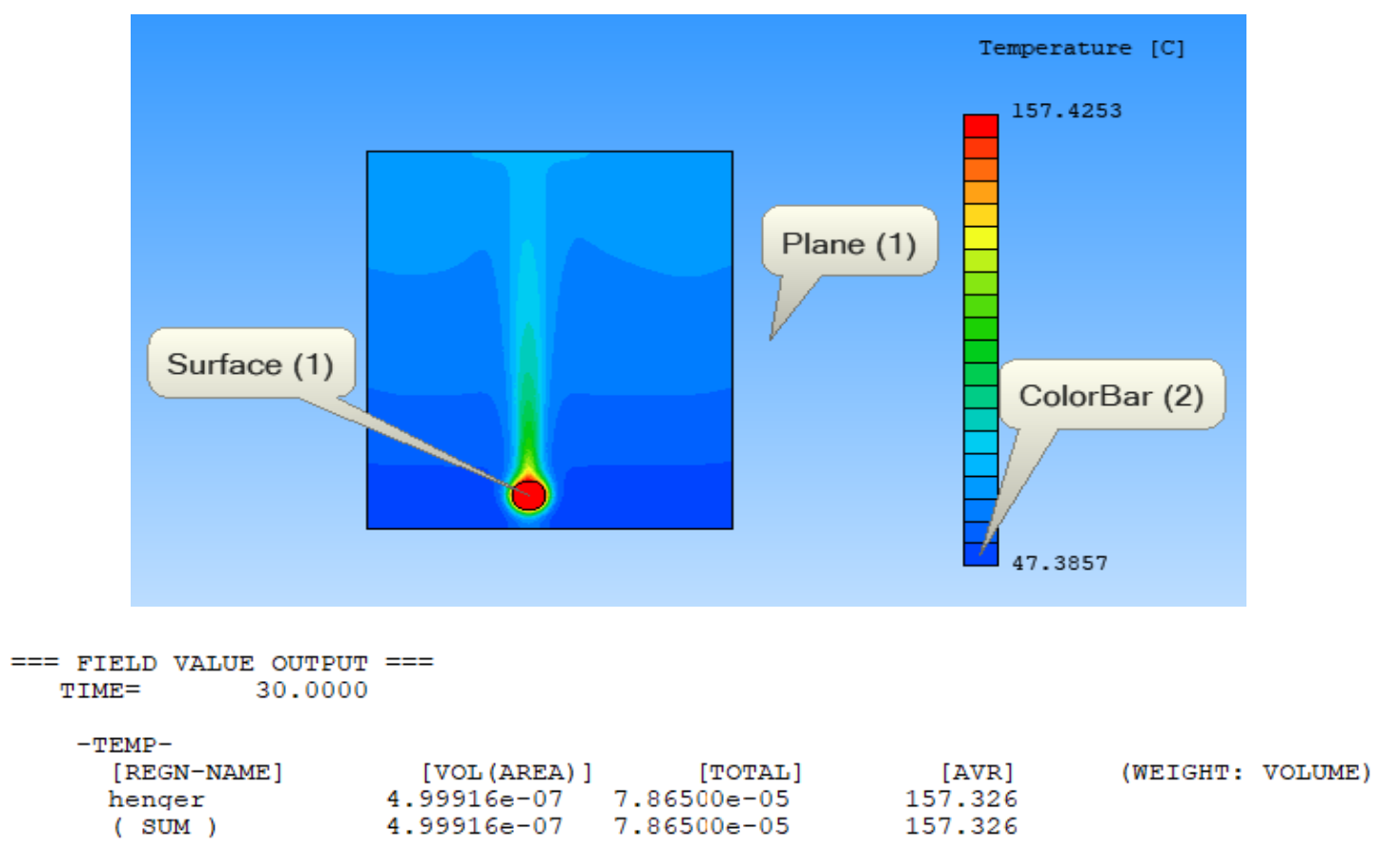

\section{2. ábra: Szabad konvekció henger esetén}

Az áramlási képen látszik, hogy valóban szabad konvekciós hőátadás lépett fel, mivel a gravitációs gyorsulás vektorával ellentétes irányban áramlik fel a felmelegedett levegő, valamint az is látható, hogy a befoglaló térfogat elegendően nagy a vizsgálathoz, mivel az adiabatikus falakról nincs visszahatás a vizsgált próbatestre. Az összesítő táblázatban pedig a próbatest átlaghőmérséklete látható, mely alapján $30 \mathrm{~s}$ hülés után $157,326^{\circ} \mathrm{C}$ hőmérsékletre hült le. 


\section{Számítások és szimulációk összehasonlítása}

A 2. táblázatban a gömb geometriára vonatkozó számítással és szimulációval kapott értékek bemutatása történik különböző geometriák és konvekciós esetek esetén. Ebben az esetben kényszerkonvekciós hőátadást vizsgáltunk, melyhez a (17) összefüggést alkalmaztuk.

2. táblázat. Gömb geometria eredményei

\begin{tabular}{|c|c|c|c|c|}
\hline $\begin{array}{c}\text { Gömb átmérö } \\
(\mathrm{mm})\end{array}$ & $\begin{array}{c}\text { Aramlási sebesség } \\
(\mathrm{m} / \mathrm{s})\end{array}$ & $\begin{array}{c}\text { CFD szimuláció eredmény } \\
\left({ }^{\circ} \mathrm{C}\right)\end{array}$ & $\begin{array}{l}\text { Matematikai eredmény } \\
\left({ }^{\circ} \mathrm{C}\right)\end{array}$ & $\begin{array}{c}\text { Relatív hiba } \\
(\%)\end{array}$ \\
\hline \multirow{5}{*}{ 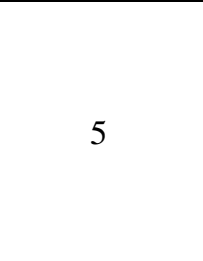 } & 0,1 & 135,8 & 138,3 & 1,741 \\
\hline & 0,5 & 117,6 & 120,6 & 2,432 \\
\hline & 1 & 102,5 & 108,6 & 5,578 \\
\hline & 1,5 & 90,7 & 100,2 & 9,463 \\
\hline & 2 & 81,4 & 93,7 & 13,054 \\
\hline \multirow{5}{*}{6} & 0,1 & 141,1 & 146,1 & 3,391 \\
\hline & 0,5 & 125,6 & 131,3 & 4,316 \\
\hline & 1 & 109,9 & 120,9 & 9,049 \\
\hline & 1,5 & 101,5 & 113,4 & 10,505 \\
\hline & 2 & 92,6 & 107,5 & 13,774 \\
\hline \multirow{5}{*}{8} & 0,1 & 151,3 & 154,9 & 2,281 \\
\hline & 0,5 & 137,3 & 144,2 & 4,753 \\
\hline & 1 & 125,7 & 136,3 & 7,813 \\
\hline & 1,5 & 117,5 & 130,5 & 9,940 \\
\hline & 2 & 111,1 & 125,8 & 11,658 \\
\hline \multirow{5}{*}{10} & 0,1 & 153,3 & 159,4 & 3,797 \\
\hline & 0,5 & 146,4 & 151,4 & 3,255 \\
\hline & 1 & 135,9 & 145,3 & 6,415 \\
\hline & 1,5 & 125,7 & 140,7 & 10,601 \\
\hline & 2 & 123,7 & 136,9 & 9,568 \\
\hline \multirow{5}{*}{12} & 0,1 & 159,3 & 162,1 & 1,751 \\
\hline & 0,5 & 153,3 & 155,8 & 1,573 \\
\hline & 1 & 144,7 & 150,9 & 4,103 \\
\hline & 1,5 & 132,9 & 147,2 & 9,704 \\
\hline & 2 & 129,5 & 144,1 & 10,130 \\
\hline
\end{tabular}

A táblázat alapján megállapítható, hogy a hiba minden esetben pozitív érték, ami azt jelenti, hogy a matematikai modellből származó eredmények minden esetben nagyobbak, mint a szimuláció által szolgáltatott hőmérséklet. Továbbá megfigyelhető az is, hogy a sebesség növekedésével a relatív hiba értéke is nő. Ez az eltérés az áramlási viszonyokból, valamint a matematikai modell alkalmazhatósági határához való közelségböl eredhet. 
Megállapítható, hogy golyó lehütése esetén a koncentrált paraméterü modell alkalmazása a célszerü, mivel a golyó teljes lehüléséhez szükséges idő ebben az esetben nagyobbra adódik, így elkerülhetők a véletlen érintésből származó emberi sérülések. Másfelől a gyártmány így biztos eléri az elöírt hőmérsékletét az adott idő alatt, a matematikai modell alkalmazásával a biztonság felé tévedünk. $\mathrm{Az}$ alábbi táblázatban a hengergörgőre végzett számítások és szimulációk eredménye kerül összevetésre. A henger geometria esetén két eset feltételezhető: (1) a henger tengelye párhuzamos az áramlás irányával (1. eset), (2) a henger tengelye merőleges az áramlás irányára és vízszintes (2. eset).

3. táblázat. Hengergeometria eredményei (1. eset)

\begin{tabular}{|c|c|c|c|c|}
\hline \multirow{2}{*}{ Henger méret $(\mathrm{mm})$} & $\begin{array}{c}\text { Áramlási sebesség } \\
(\mathrm{m} / \mathrm{s})\end{array}$ & $\begin{array}{c}\text { CFD szimuláció } \\
\text { eredmény 1.eset }\left({ }^{\circ} \mathrm{C}\right)\end{array}$ & $\begin{array}{c}\text { CFD szimuláció } \\
\text { eredmény 2.eset } \\
\left({ }^{\circ} \mathrm{C}\right)\end{array}$ & hiba $(\%)$ \\
\hline \multirow{4}{*}{$\mathrm{D}=8 \mathrm{~mm}, \mathrm{~L}=10 \mathrm{~mm}$} & 0,1 & 154,1 & 154,5 & 0,268 \\
\cline { 2 - 5 } & 0,5 & 148,5 & 144,7 & $-2,636$ \\
\cline { 2 - 5 } & 1 & 138,5 & 134,7 & $-2,830$ \\
\cline { 2 - 5 } & 1,5 & 118,4 & 127,4 & 7,011 \\
\hline \multirow{3}{*}{$\mathrm{D}=10 \mathrm{~mm}, \mathrm{~L}=11 \mathrm{~mm}$} & 2 & 112,7 & 121,3 & 7,071 \\
\cline { 2 - 5 } & 0,1 & 157,2 & 158,4 & 0,711 \\
\cline { 2 - 5 } & 0,5 & 149,6 & 151,5 & 1,200 \\
\cline { 2 - 5 } & 1 & 140,0 & 142,4 & 1,706 \\
\cline { 2 - 5 } & 1,5 & 132,5 & 136,2 & 2,772 \\
\hline
\end{tabular}

Látható, hogy kis sebesség esetén a hőmérsékletek között nincs számottevő különbség. A geometria növelésével a különbségek a sebesség növelése mellett is csak kis mértékben változnak. Ebből következően a hengerek pozíciójáról a hőkezelés végén nem feltétlen kell gondoskodni. A számítási és a szimulációs módszer közti különbséget abban az esetben, mikor a henger áramlással párhuzamos pozícióban található, a 4. táblázat szemlélteti.

4. táblázat. Hengergeometria eredményei (2. eset)

\begin{tabular}{|c|c|c|c|c|}
\hline Henger méret $(\mathrm{mm})$ & $\begin{array}{c}\text { Aramlási sebesség } \\
(\mathrm{m} / \mathrm{s})\end{array}$ & $\begin{array}{c}\text { CFD szimuláció eredmény } \\
1 . \text { eset }\left({ }^{\circ} \mathrm{C}\right) \\
\end{array}$ & $\begin{array}{l}\text { Matematikai } \\
\text { eredmény }\left({ }^{\circ} \mathrm{C}\right)\end{array}$ & $\begin{array}{l}\text { Relatív hiba } \\
\text { 1.eset }(\%) \\
\end{array}$ \\
\hline \multirow{5}{*}{$\mathrm{D}=8 \mathrm{~mm}, \mathrm{~L}=10 \mathrm{~mm}$} & 0,1 & 154,1 & 160,0 & 3,721 \\
\hline & 0,5 & 148,5 & 149,5 & 0,685 \\
\hline & 1 & 138,5 & 142,2 & 2,549 \\
\hline & 1,5 & 118,5 & 136,8 & 13,368 \\
\hline & 2 & 112,7 & 132,4 & 14,858 \\
\hline \multirow{5}{*}{$\begin{array}{l}\mathrm{D}=10 \mathrm{~mm} \\
\mathrm{~L}=11 \mathrm{~mm}\end{array}$} & 0,1 & 157,3 & 162,6 & 3,266 \\
\hline & 0,5 & 149,6 & 154,6 & 3,185 \\
\hline & 1 & 140,0 & 148,8 & 5,894 \\
\hline & 1,5 & 132,5 & 144,5 & 8,330 \\
\hline & 2 & 126,7 & 141,0 & 10,130 \\
\hline
\end{tabular}


Látható, hogy itt nagyobb eltérések adódnak a módszerek között, mint a gömb esetében, de a hibák itt is zérustól nagyobb értékúek. Tehát megállapítható, hogy a koncentrált paraméterü modell alkalmazása, gömb és henger geometria esetén is a biztonság felé való tévedést eredményezi.

\section{Gömbök kölcsönhatása}

A következő lépésben azt vizsgáltuk, hogy mi történik abban az esetben, ha nem egyetlen testet elemzünk, hanem a légáramlás irányában több test is van. A kérdés ilyenkor az, hogy milyen távolságok esetén tekinthetők egyedülálló testnek, és mikor kell rendszerként tekinteni rájuk. A légáramlásra soros elrendezés esetén az első test által felmelegített levegő hüti a következő testet, de itt a levegő és a test hőmérséklet-különbsége kisebb lesz, mint az első test esetén, ezért ennek a hőmérséklete, ugyanannyi idő alatt, jelentősen nagyobb érték lesz. Az előzetes szimulációs eredmények alapján megállapítható, hogy csak bizonyos sebesség felett következik be a visszahatás jelensége. Ez azt a sebességet jelenti, ahol a test által kibocsátott höáram iránya közel vízszintes. Ez az eddigi eredmények alapján megközelítőleg $1 \frac{\mathrm{m}}{\mathrm{s}}$ sebességü áramlás esetén következik be.

A szimulációkat 3 darab $D=6 \mathrm{~mm}$ átmérőjủ csapágygolyóval végeztük el, amelyek egymástól mért távolsága $1 \mathrm{D}, 2 \mathrm{D}$, illetve $3 \mathrm{D}$ volt. A vizsgálati idő itt is változatlanul 30 másodperc volt. A kapott eredményeket az alábbi 5. táblázat szemlélteti.

5. táblázat. Gömb geometriák kölcsönhatása

\begin{tabular}{|c|c|c|c|c|}
\cline { 3 - 5 } \multicolumn{2}{c|}{} & \multicolumn{3}{c|}{$\begin{array}{c}\text { Golyók kialakuló } \\
\text { hömérséklete }\left[{ }^{\circ} \mathrm{C}\right]\end{array}$} \\
\cline { 3 - 6 } \multicolumn{2}{c|}{} & 1. golyó & 2. golyó & 3. golyó \\
\hline \multirow{3}{*}{$\begin{array}{c}\text { Golyók távolsága } \\
\text { egymástól }\end{array}$} & 1D & 102,8 & 132,9 & 136,2 \\
\cline { 2 - 5 } & 2D & 95,9 & 127,6 & 131,5 \\
\cline { 2 - 5 } & 3D & 95,8 & 123,3 & 127,4 \\
\hline
\end{tabular}

A fenti táblázat alapján kijelenthető, hogy minél távolabb helyezzük el egymástól a testeket, annál gyorsabb lehülést érhetünk el. A golyók távolságára abban az esetben kell figyelmet fordítani, ha a ventilátor által létrehozott áramlás sebessége $1 \frac{\mathrm{m}}{\mathrm{s}}$.

Ezek alapján azt az intézkedést lehet javasolni, a minél gyorsabb hütés érdekében, hogy a megeresztést követően ne egysoros elrendezésben hagyják el a kemencét a testek, a ventilátor által keltett légmozgás pedig legyen merőleges a golyók haladási irányára.

\section{6. Összefoglalás}

Jelen tanulmány alapvető célja az egyszerüsített matematikai és empirikus modellek CFD-analízissel történő validálása volt. Az összehasonlító táblázatokból egyértelműen látszik, hogy a tapasztalati összefüggések kisebb közegsebességek esetén megbízhatóbb eredményt adtak, mint nagyobb sebességek esetén, viszont egy meglévő matematikai modellel történő számítás számítási ideje nagyságrendekkel kisebb, mint minden egyes modell implementálása valamilyen CFD rendszerbe. Egy ilyen modell alkalmazásával, bizonyos mérettartományok esetén nagyon jó becslést tudunk adni a 
vizsgált próbatestek hőmérsékletének változására, így változtatva bizonyos üzemeltetési paramétereket (légsebesség, futószalag sebessége, futószalag hossza, próbatestek elhelyezése).

\section{Irodalom}

[1] Corrêa, E.J., Cotta, R.M.: Enhanced lumped-differential formulations of diffusion problems. Appl. Math. Model 1998, 22(3):137-152, 1998. https://doi.org/10.1016/S0307904X(98)00005-5

[2] Bertoli, S.L., de Almeida, J., de Souza, C.K., Lovatel, A., Padoin, N., Soares, C.: Lumped analysis criteria for heat transfer in a diluted co - current moving bed heat exchanger with isothermal walls. Powder Technol. 2019, 361:1038-1059. https://doi.org/10.1016/j.powtec.2019.10.092

[3] Cengel, Y.A.: Heat Transfer - A Practical Approach. Second Edition. McGraw-Hill International Editions, 2002.

[4] Cole, K.D., Beck, J.V., Woodbury, K.A., de Monte, F.: Intrinsic verification and a heat conduction database. Int. J. Therm. Sci. 2014, 78:36-47. https://doi.org/10.1016/j.ijthermalsci.2013.11.002

[5] Bergman, T.L., Lavine, A.S., Incropera, F.P., Dewitt, D.P.: Fundamentals of Heat and Mass Transfer, Seventh Ed. Wiley, 2011.

[6] Churchill, S.W., Chu, H.H.S.: Correlating equations for laminar and turbulent free convection from a vertical plate. Int. J. Heat Mass Transf. 1975, 18(11):1323-1329. https:/doi.org/10.1016/0017-9310(75)90243-4

[7] Whitaker, S. Forced convection heat transfer correlations for flow in pipes, past flat plates, single cylinders, single spheres, and for flow in packed beds and tube bundles. AIChE 1972, J18:361-371. https://doi.org/10.1002/aic.690180219

[8] Li, P., Li, Y.M., Leong, J.C.: Lumped-system analysis of a cavity with triangular porous layers. Appl. Math. Model. 2015, 39(18):5507-5520. https://doi.org/10.1016/j.apm.2014.12.031

[9] Malekzadeh, P., Rahideh, H.: IDQ two-dimensional nonlinear transient heat transfer analysis of variable section annular fins. Energy Convers. Manag. 2007, 48(1):269-276. https://doi.org/10.1016/j.enconman.2006.04.005 